九州大学学術情報リポジトリ

Kyushu University Institutional Repository

\title{
On a Method for the Recognition of Differentiation of Fossil Foraminiferal Fauna
}

Kameyama, Tokuhiko

Faculty of Science, Kyushu University

https://doi.org/10.5109/1543908

出版情報：九州大學理學部紀要：Series D, Geology. 20 (1)，pp.59-71，1970-01-25. Faculty of Science, Kyushu University バージョン：

権利関係 : 
Mem. Fac. Sci., Kyushu Univ., Ser. D, Geology, Vol. XX, No. 1, pp. 59-71, text-figs. 1-4, tables 1-2, Jan. 25, 1970

\title{
On a Method for the Recognition of Differentiation of Fossil Foraminiferal Fauna
}

By

Tokuhiko KAMEYAMA

\begin{abstract}
This study is carried out to establish the grouping method of the fossil foraminiferal fauna as the first step for the paleoecological work of the benthonic foraminiferal fauna.

The ordinary methods in such fields have been based chiefly on the qualitative characteristics of the faunal assemblages up to now. In recent years, some statistical methods were introduced to divide the differentiated recent fauna objectively, but the application of these statistical methods for the fossil material have not been reported yet. Cluster analysis is applied in this study to recognize the differentiation of the fossil foraminiferal fauna.

The formulas used in this study are Morisita's Index for the calculation of the similarity between samples and the SPEARMAN's sums of variable formula for the clustering and reclustering. Although both of the formulas were invented to analyse the living fauna, the present result shows that they are applicable for the fossil material. The result is harmonious with and more objective than those of the qualitative method on the Miyazaki Group, and affords the basis for the further ecological consideration.
\end{abstract}

\section{Introduction}

In the history of the ecological study of the benthonic foraminifers the research on the synecology started first and has taken the lead of all the branches of that study. This is very natural because of the minute size and abundant occurrence of the benthonic foraminifers. Abundant occurrence stimulates to treat the object as foraminiferal community, while the minute size makes difficult to observe the individual activity. Furthermore in case of the fossil material of the benthonic foraminifers the synecology is much more practical than other branches of ecology.

The first step of the synecology is the recognition and distinction of the communities. Much debate has been concerned with the objectivity for the distinction. The recognition of differentiation of the foraminiferal fauna was originally based, historically speaking, chiefly on the qualitative and partly quantitative characteristics of the faunal assemblages. Species of geographically limited distribution but of common or abundant occurrence are selected as the representative species. Assemblages characterized respectively by co-occurrence of a few of them are grouped as communities, which are called after the name

Manuscript received July 24, 1969. 
of the representative species. The merit of this method lies in that the image of the faunal character of the assemblages is readily comprehensible for the reader. This method, however, holds several faults in itself. Among them the most serious are that (1) the subjectivity cannot be avoided to select the representative species, (2) the species with dense population and geographically wide distribution tend to be neglected, (3) while the species occurring in the special samples may be highly evaluated, even if the number of individuals is small. This tendency seems to have been exaggerated in the study of the benthonic foraminifers. It is simply because that many species of dense population occur in the samples of several stations in one area and consequently the distinctive character of the assemblages may be diluted, if the importance is put on the dominant species.

To overcome the faults mentioned above and carry out the study as objectively as possible, some statistical methods were introduced recently for the recognition of the differentiation of recent benthonic foraminifers. The assemblages are clustered through calculation of a number of species and/or individuals of the assemblages (KAESLER, 1966; BUZAS, 1968; MELLO and BUZAS, 1968).

Among several formulas proposed for this purpose, Coefficient of JACCARD, Simple matching coefficient, SImPson's Index 2 etc. have become popular. These formulas, however, also have some considerable faults respectively, and these faults are especially emphasized in case of the fossil material. While the formula proposed by MoRIsITA (1959a, b) verifies that it is applicable to the fossil material with least biased result. Hence I adopt MoRIsITA's Index in this paleontological study for the calculation of similarity among the samples and SPEARMAN's sums of variable formula (SOKAL and SNEATH, 1963) for the clustering and the reclustering.

The material for the study was obtained from the Miyazaki Group (Upper Miocene to Lower Pliocene) in southeast Kyushu, Japan. This group is considered to be one of the most appropriate stratigraphic unit for the paleontological study, because (1) it has been extensively studied in detail by several researchers and (2) it is, on one hand, differentiated in three major sedimentary facies laterally, and on the other hand, it consists of two major cycles of sedimentation vertically (ShUTO; 1952, 1961). YокоYамA (1928), ОтUKA (1930), UсHIO (1947), MuRATA (1951) and ShUto (1952-1961) contributed to the stratigraphical and paleontological investigation of that group. The last author, especially, gave the comprehensive result of the stratigraphic work of the whole area and of the molluscan paleontology.

I have been working on the benthonic foraminifers of the Miyazaki Group for more than two years. The material was obtained along three stratigraphic sections in the northern area of distribution. A part of the result was already offered (KAMEYAMA; 1969). 

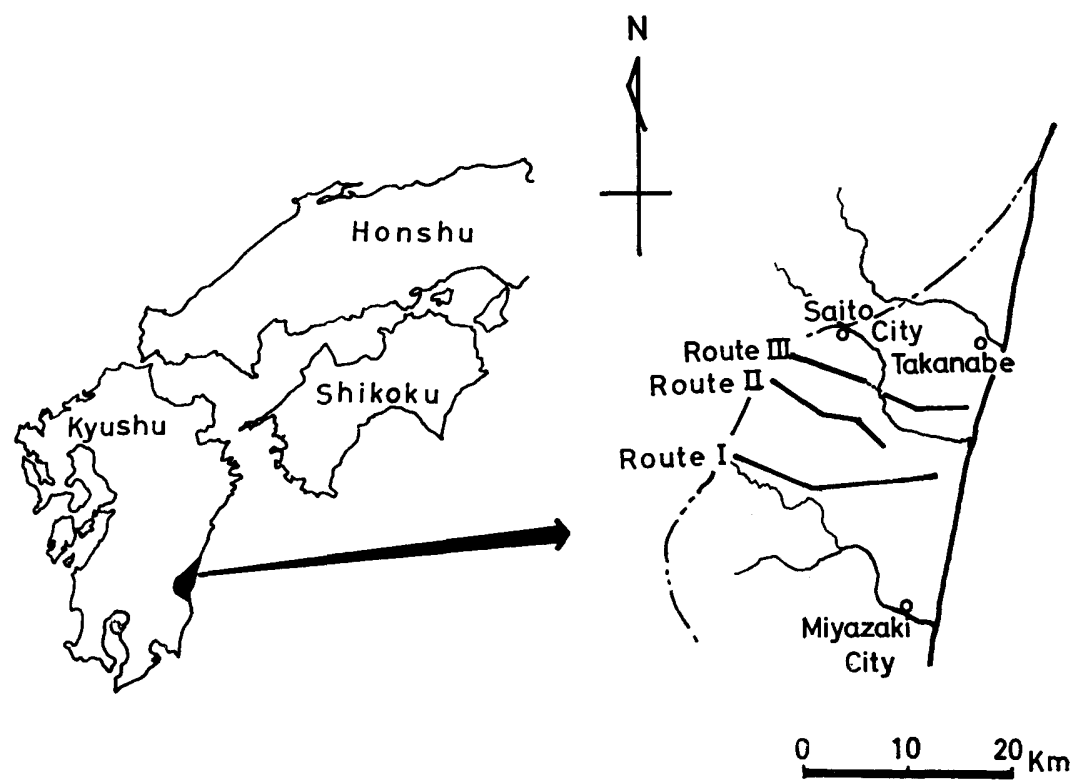

Fig. 1. Index map showing the sampling routes.

\section{Acknowledgements}

I wish to express my cordial thanks to Professor Ryuzo ToniYama of Kyushu University for his appropriate guidance and criticism. I am deeply indebted to Assistant Professor Tsugio SHUTo of the same university for his kind advice, valuable criticism and appropriate suggestion at which the study have been carried out, and had a critical read of the manuscript. I am also deeply indebted to Dr. Juichi YANAGIDA for his kind help and encouragement in the course of the study. Dr. Itaru Hayami and Mr. Tomowo Ozawa gave me valuable suggestions and advice concerning the statistical methods.

I wish to express here my hearty thanks to these persons without whose supports the work could not have been executed.

\section{Method}

\section{(I) Sampling}

Three routes (Route I, II and III) were selected so as to represent the major sedimentary facies. The routes are separated by roughly equal distance and cross the strike of the strata at rihgt angle. The sampling localities were chosen at equal intervals, but in practice the intervals were more or less modified under the particular field conditions.

The procedure of the preparation of the rock sample is briefly described below. Dried rock sample is weighed at about $200 \mathrm{gr}$. and crushed in an ironmorter. Then it is treated with the oversaturated solution of sodium sulfate $\left(\mathrm{Na}_{2} \mathrm{SO}_{4}\right)$ to disintegrate it. After that the sample is crushed by the Roller-Mill. 
The crushed sample is then washed by water through the sieve of 115 mesh and 200 mesh. The residues on the sieve of 115 mesh are dried on the sand-bath, and then the foraminifers are identified and counted under the binocular microscope.

If the prepared sample contains only a small number of individuals of foraminifers, the whole individuals in a sample are counted, while in the case that the number of individuals is great, the sample is divided into small fraction through the two-fold division before counting. After that whole number of individuals in each sample is totaled.

Among 77 examined samples, 65 contained fossil foraminifers. Whole number of species contained in those 65 samples is 228 . The greatest number of individuals of the benthonic foraminifers in one sample is 4330 of sample number 100 , while the smallest is 9 of sample number 8545 and this sample is almost meaningless for the calculation. The average number of individuals in each sample is about $900-1,000$.

\section{(II) Probability models}

Several coefficients were devised to estimate the similarity between samples. The leading examples which have been frequently applied in the biological and paleontological study are as follows:

Coefficient of JACCARD

$$
S_{j}=\frac{N_{J K}}{N_{J K}+N_{j K}+N_{J k}}
$$

Simple matching coefficient

$$
S_{s m}=\frac{N_{J K}+N_{j k}}{N_{J K}+N_{j k}+N_{j K}+N_{J k}}
$$

SIMPSON's Index

$$
S_{s}=\frac{N_{J K}}{N_{\min }(J . K)}
$$

where $J$ and $\mathrm{K}$ represent respectively the sample compared, $N_{J K}$ is the number of species contained in common in the sample $\mathrm{J}$ and $\mathrm{K}, N_{j K}$ is the number of species present in the sample $\mathrm{K}$ but absent in the sample $\mathrm{J}, N_{J k}$ is the number of species present in the sample $\mathrm{J}$ but absent in the sample $\mathrm{K}, N_{j k}$ is the number of species in the whole fauna under consideration but absent in both samples $J$ and $K$, and $N_{\min }(\mathrm{J} . \mathrm{K})$ is the number of species in the smaller sample $\mathrm{J}$ or $\mathrm{K}$.

The advantage claimed for these coefficients is easiness of calculation, but they have the fatal fault that the number of individuals of each species is left out of the consideration and the dominant and inferior species are evaluated quite equally. It cannot be avoided that the same weight is put on the indigenous species and the species transported accidentally from the other area, because the factors of these formulas are simply based on present or absent of the species. The value calculated by these formulas changes remarkably, because each of $N_{J K}$, $N_{j K}, N_{J k}$ and $N_{j k}$ changes irregularly according to the size of "quadrata", which in turn affects the number of species, even if "quadrata" settled at the same point. 
Furthermore in the formula of Simple matching coefficient the total number of species of the surveyed area is taken as a factor, and it may overwhelm the other factors, $N_{J_{K}}, N_{j K}$ and $N_{J k}$, when the total number of species is very great. Wide area, especially complicatedly differentiated area which afford the variable habitats for the organisms, usually corresponds with a great number of the total species. Therefore these formulas are applicable only when the surveyed area is narrower than certain extent and each quadrata is settled by strictly similar way to the others.

The severe conditions of these formulas mentioned above reveal the difficulty in application of them to the large fossil fauna in a wide area, where the sampling is remarkably influenced by the field conditions.

Hence the formula proposed by Morisita (1959a, b) was examined.

It is

$$
C_{\lambda}=\frac{2 \sum_{i=1}^{\infty} n_{1 i} n_{2 i}}{\left(\lambda_{1}+\lambda_{2}\right) N_{1} N_{2}} \quad \lambda=\frac{\sum_{i=1}^{\infty} n_{i}\left(n_{i}-1\right)}{N(N-1)}
$$

where $N_{i}$ is the total number of individuals of foraminifers of sample I and $n_{1 i}$ and $n_{2 i}$ are the number of individuals of common species $I$ in the sample 1 and 2 . Possible range of $C_{\lambda}$ is from 0 to $1( \pm)$.

Any deficiency mentioned above is excluded in this formula and this formula is almost not influenced by the sample size and seems to be the most suitable measure of the dispersion of individuals.

MORISITA's Index is a kind of the function of density and based on the formula

$$
\frac{n(n-1)}{N(N-1)}
$$

Accordingly, $\lambda$ indicates the degree of density of the species in a sample and $C_{\lambda}$ takes the value of unity, if the individuals are distributed at random. It takes the value smaller or larger than unity, if the distribution is uniform or contagious correspondingly. This formula was applied for the analysis of the living fauna and flora in the branch of biology (ONO, 1962, 1965; TAGAWA, 1964).

In case of application of the statistical formula for the community paleoecology of the fossil fauna, it is a natural question whether or not the calculated values are useful for the basis of the ecological comparison, when any of the elements of the fauna become extinct within the time-span under consideration. Because, in such a case as mentioned above, the similar value cannot be expected between the older and younger assemblage of even quite similar ecological environments. Actually, however, this question is not appropriate.

One cannot deal with the ecological condition, but with only the similarity of the assemblages in terms of the species and number of the individuals by MoRISITA's Index. One can identify or distinguish the assemblages regardless of the extinction or survival of the element in the course of the time under consideration. Effect of "extinction" should be considered carefully at the time of 
examination of paleoecology of the assemblages. This is apparently the next stage of the procedure.

The time-span of the Miyazaki Group is from Upper Miocene to Lower Pliocene at least. As far as my observation is concerned, though limited, all the benthonic foraminiferal species of the lower Miyazaki Group survive through Miocene, but some species appear at the age of Pliocene. The appearance of these new comers apparently has an effect on the dendrogram, although the influence is not so great. This should be weighed in the consideration of ecological problems.

\section{(III) Clustering method}

The clustering is carried out using the SPEARMAN's sums of variable formula. This formula is

$$
r_{q Q}=\frac{\square q Q}{\sqrt{q+2 \Delta \bar{q}} \sqrt{Q+2 \Delta Q}}
$$

where, $\square \mathrm{qQ}$ is the sum of all correlations between members of one group with the other group, $\Delta \mathrm{q}$ is the sum of all correlations between members of the first group, $\Delta \mathrm{Q}$ is a similar sum between members of the second group, $\mathrm{q}$ is the number of members in the first group, and $Q$ is the number of members in the second group. The matrix made of similarity coefficient is examined by this method to cluster.

\section{Discussion}

The evaluation of the methods applied to this study depends apparently upon the understanding whether the divisions of the successive fossil assemblages are statistically appropriate or not and whether these divisions exactly correspond to the particular environmental condition. The first problem was already answered in the foregoing paragraphs. The second problem has the implication whether the established clusters are ecologically significant or not. This problem should be examined at the next phase of the study.

The result of the Q-mode (sample by sample) analysis is shown in the dendrograms of the Text-figure 2. 65 samples are grouped into 17 at the 0.45 phenon. These groups are documented as " $A$ ", " $B$ ", " $C$ " ... and " $Q$ " respectively.

The characters of these groups (A to $Q$ ) may be shown most typically by the assemblages of the couples of samples clustered at first in each group. The character of the sample clustered in a particular group at a low level in a dendrogram, that is to say, the character of the assemblage showing the marginal feature of that group, is remarkably different from the typical character of that group. It is almost impossible to decide objectively which group the assemblages of the marginal characters mentioned above belong to. In the qualitative procedure the boundary of the groups is set subjectively, but in the present procedure it is done objectively.

Comparison of the result with that by the qualitative method: By the qualitative method, the foraminifers of these samples are divided into 15 assemblages, 


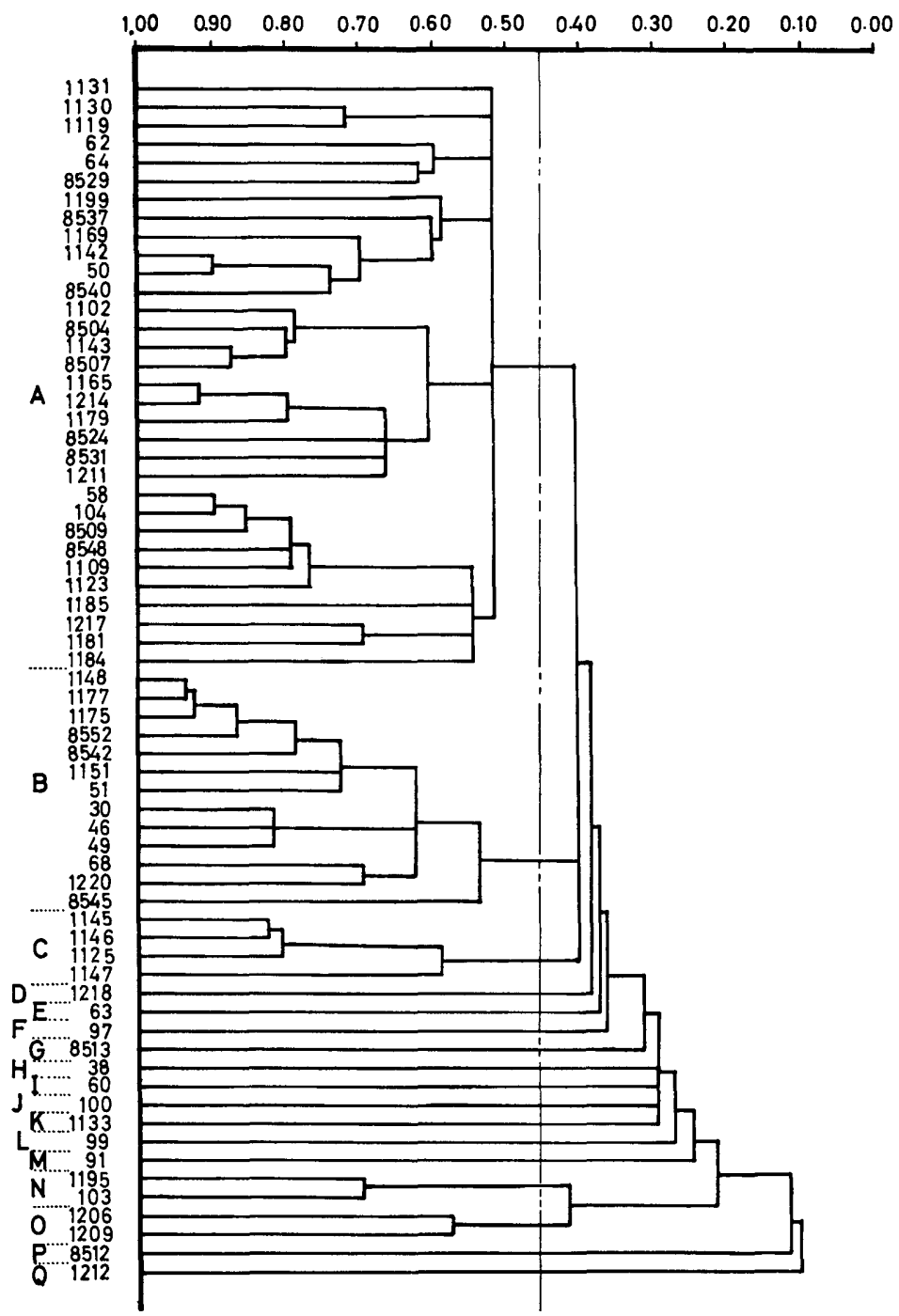

Fig. 2. Dendrogram of Q-mode (sample by sample) analysis.

that is to say, these samples are divided into 15 groups. These assemblages, which, of course, change the character gradually in each other, are as follows.

(I) Uvigerina excellens-Cibicides lobatulus assemblage:

Typical sample: 58.

Dominant species: Uvigerina excellens (45.8\%).

Characteristic species: Cibicides lobatulus.

Locality: 8509, 58, 104, 8548, 1109, 1123, 1184, 1185, 1218.

When the number of individuals of Uvigerina excellens is smaller, the number of Cibicides lobatulus is greater. This assemblage changes its composition and grades to II and III assemblage.

(II) Bolivinita quadrilatera-Sigmoilopsis schlumbergeri-Uvigerina excellens assemblage: 

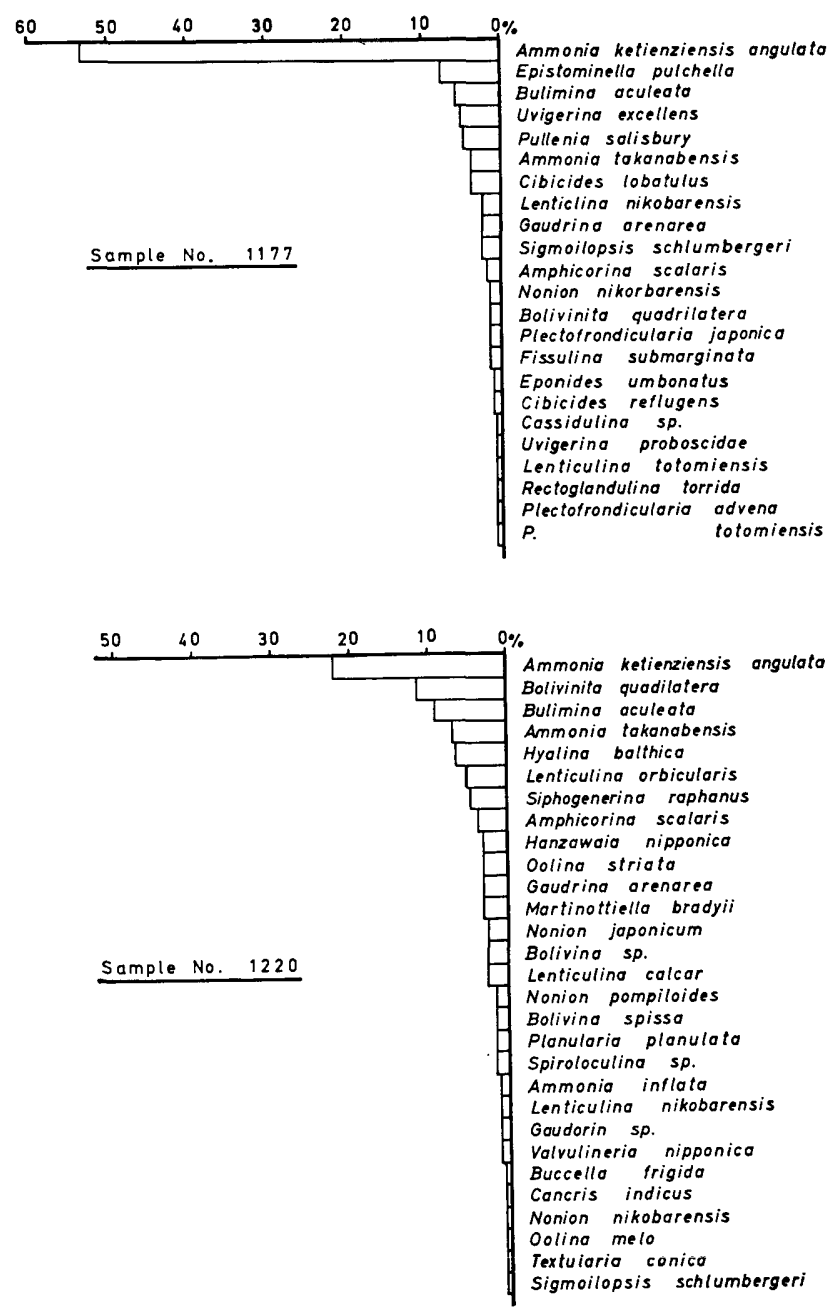

Fig. 3. Character of faunal assemblages in the Group B. 1177 is the typical and 1220 is the marginal examle.

Typical sample: 8540 .

Dominant species: Bolivinita quadrilatera (27.7\%).

Characteristic species: Sigmoilopsis schlumbergeri.

Locality: 1142, 8540, 50, 8537, 1169, 1199.

This assemblage changes to the assemblages I, III and V gradually.

(III) Nonion nikobarense-Sigmoilopsis schlumbergeri-Uvigerina excellens assemblage:

Typical sample: 8531.

Dominant species: Nonion nikobarense (28.1\%), Sigmoilopsis schlumbergeri $(12.5 \%)$.

Characteristic species: Uvigerina excellens.

Locality: 8531, 1211, 8524, 1179, 1214, 1165, 1102, 8504, 8507, 1143.

In this assemblage the dominant species is not so clear. In the atypical 
samples the number of individuals of Loxostomum karrerianum becomes great, and the character becomes similar to $\mathrm{X}$ assemblage gradually.

(IV) Bulimina aculeata-Uvigerina excellens assemblage:

Typical sample: 64 .

Dominant species: Bulimina aculeata (33.7\%).

Characteristic species: Uvigerina excellens (10.6\%).

Locality: 64 .

This assemblage is somewhat similar to $\mathrm{X}$ assemblage but in $\mathrm{X}$ assemblage Uvigerina excellens is a minority.

(V) Ammonia ketienziensis angulata-Cibicides spp. assemblage:

Typical sample: 8552 and 1177.

Dominant species: Ammonia ketienziensis angulata $(41.5 \%, 54.3 \%)$.

Characteristic species: Cibicides lobatulus, C. aknerianus and C. pseudoungerianus.

Locality: $46,1175,8552,1220,49,1177,8542,1148,1151,30,68,51,99$.

Cibicides spp. of the characteristic species are not necessary to appear together in a sample, but generally appear separately in each sample. In the atypical samples the dominant species becomes indistinct or Cibicides spp. become extinct as shown in the sample 1220 and 68 .

(VI) Cibicides praecinctus-Nonion nikobarense-Sigmoilopsis schlumbergeri assemblage:

Typical sample: 1125 .

Dominant species: Cibicides praecinctus $(28.0 \%)$, Nonion nikobarense $(18.7 \%)$.

Characteristic species: Sigmoilopsis schlumbergeri.

Locality: 1125, 1146, 1145, 1147.

In this assemblage the dominant species is not so clear. For example, the dominant species in the sample 1147 is Rectobolivina bifrons, and Nonion nikobarense is a minority but both of Cibicides praecinctus and Sigmoilopsis schlumbergeri are the dominant species and then this sample is included in this assemblage.

(VII) Ammonia papillosa-Siphogenerina raphanus assemblage:

Typical sample: 1206.

Dominant species: Ammonia papillosa (82.0\%).

Characteristic species: Siphogenerina raphanus.

Locality: 1206, 1209, 103, 1195.

In the atypical case, as the sample 103 and 1195, Ammonia inflata and Bolivinita subangularis become dominant. This suggests possibility to divide this assemblage into two characterized respectively by Ammonia inflata and A. papillosa, and A. papillosa and Siphogenerina raphanus.

(VIII) Rectobolivina columellaris - Nonion nikobarense - Plectofrondicularia totomiensis assemblage:

This assemblage includes the foraminifers of two samples, 1119 and 1130 , and is characterized by abundant occurrence of Rectobolivina columellaris (16.2 and $21.5 \%$ ) and attendance of Plectofrondicularia totomiensis, but in this assemblage the dominancy is not so clear. This assemblage is not distinguished 
from VI assemblage clearly.

(IX) Hanzawaia nipponica-Cibicides spp. assemblage:

This assemblage consists of foraminifers respectively of four samples, 1131, 100,1133 and 8512, and is characterized by the presence of Hanzawaia nipponica but there is not a definite character and may be divided into four subassemblages respectively. The first is Hanzawaia nipponica-Eggerella propinqua, the second is Cibicides subhaidingerii-Hanzawaia nipponica, the third is Hanzawaia nipponica-Amphistegina quoyii and the fourth is Elphidium advenum-Hanzawaia nipponica subassemblages.

(X) Bulimina aculeata-Loxostomum karrerianum assemblage:

Typical sample: 8529 .

Dominant species: Bulimina aculeata $(\mathbf{1 7 . 8 \% )}$, Loxostomum karrerianum $(15.0 \%)$.

Locality: $8529,62,63,91$.

In this assemblage the dominancy is not so clear.

(XI) Uvigerina nitidula-Bolivinita quadrilatera assemblage:

Foraminifers of two samples, 97 and 1212, represent this assemblage. The common character of this assemblage is the abundant occurrence of $U$. nitidula only.

(XII) Bolivina spissa-Bolivinita quadrilatera assemblage:

This assemblage includes foraminifers of two samples, 1217 and 1181, and is characterized by the abundant occurrence of Bolivina spissa. In this assemblage the dominancy is not so clear.

(XIII) Gyroidina orbicularis-Nonion nikobarense assemblage:

Dominant species: Gyroidina orbicularis (34.5\%).

Locality: 8513.

XIII, XIV and XV assemblages consist of foraminifers of one sample respectively and are characterized by abundant occurrence of one species. These assemblages have intermediate character of many other assemblages.

(XIV) Textularia abbreviata-Ammonia ketienziensis angulata assemblage:

Dominant and characteristic species: Textularia abbreviata $(30.6 \%)$.

Locality: 60.

(XV) Plectofrondicularia totomiensis-Bolivina spissa assemblage:

Dominant species: Plectofrondicularia totomiensis $(40.0 \%)$.

Locality: 38.

Comparison of the calculated groups (A to Q) with 15 assemblages mentioned above readily indicates the following correlation between "groups" and assemblages.

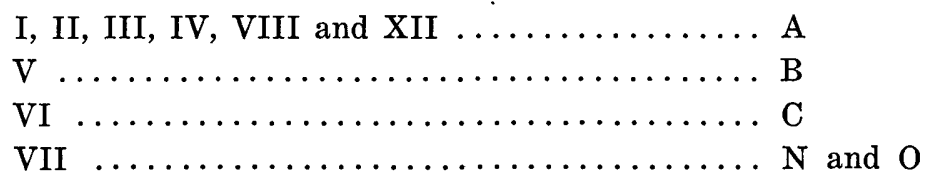

and the samples of the other assemblages are divided separately and correspond with the groups that consist of foraminifers of one sample respectively. In the group A, 6 subgroups are recognized at the 0.55 phenon and these subgroups, 
expect for one (sample 1131), correspond to the I, II, III, IV and VIII assemblages respectively.

Comparison of the result with that by the expedient method: I offered the result of calculation of the same material as the present work based on a similar method (KAMEYAMA, 1969), but in that case the similarity between samples was calculated and clustered separately for each route. Then I got the groups of 1-1 to 1-7, 2-1 to 2-4 and 3-1 to 3-6 for the Route I, II and III respectively. Finally I calculated the similarity between groups of the different Route, using the total number of individuals of species comprising respective group by MoRISITA's Index as an expedient. According to the result of calculation, similar groups between the Route I and the Route II were $2-1$ by 1-6, 2-2 by 1-5 or 1-6 and 2-3 by 1-4, those between the Route I and the Route III were 1-6 or 1-4 by 3-3, and those between the Route II and the Route III were 3-3 by 2-1, 2-2 or 2-3. The following suit, 1-5 or 1-6 by 2-2 or 2-3 by 3-3 make up a particular group with close similarity among the routes.

The present result of calculation described on page 64 is in harmony with that result just mentioned, the group A comprises a part of 1-5, 1-6, 2-1, 2-2, 2-3 and $3-3$, and the groups $\mathrm{B}, \mathrm{C}, \mathrm{N}$ and $\mathrm{O}$ correspond to 1-4, 2-3 and 3-3, 2-1 and 3-3, 1-3 and 1-2 respectively.

The one cause why 12 samples do not show any correspondence to the present groups ( $\mathrm{A}$ to $\mathrm{Q}$ ) is considered that the samples are collected from the strata distributed in wide area spanning a long time. These strata should include many natural paleoenvironments and many assemblages corresponding to these environments.

Environmental relation of the fauna: The comparison of the calculated groups with the sediments indicates that the change of the faunal assemblages doesn't necessarily correspond to the change of the macrofeatures of the lithology. The followings are necessary for the study of the relations between foraminiferal fauna and lithofacies of a wide area. (1) at the first step, in the narrower area, that is to say, at an outcrop the minute changes of foraminiferal fauna and lithofacies are investigated and then any rule or definite relationship between foraminiferal fauna and lithofacies may be recognized, and (2) on the basis of the results of (1), in the wide area the relation of the foraminiferal fauna and the lithofacies are defined. It is left for the future studies to clarify what is the real cause of the vertical and horizontal change of the fossil assemblages. Perhaps the mud content or the clay content, may be one cause (SANDERS, 1958) and on the other hand, depth and temperature of the water or other physicochemical factors may have influence on it.

\section{Conclusion}

(1) MORISITA's Index for the calculation of similarity between samples and SPEARMAN's sums of variable formula for the clustering and the reclustering are applied to the cluster analysis of fossil benthonic foraminiferal fauna. Both of them were invented for the analysis of the living fauna and flora, but have 


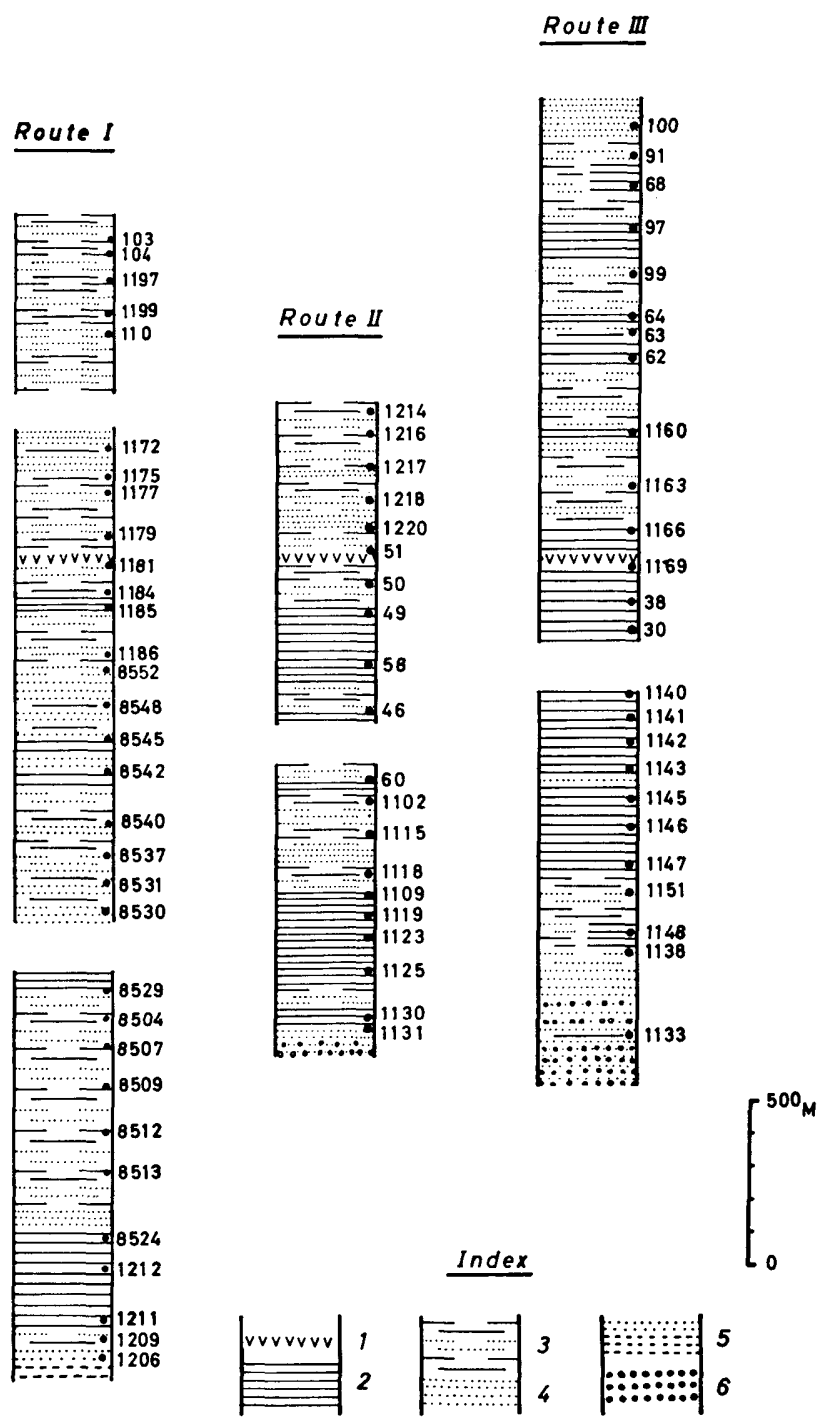

Fig. 4. Columnar sections along three routes showing sampling points. 1. tuff, 2. mudstone and siltstone, 3. alternation of sandstone and mudstone or siltstone, 4. sandstone, 5. very coarse sandstone or granule conglomerate, 6 . conglomerate.

not been applied for the fossil material. The present result shows that they are applicable for the fossil fauna.

(2) The result obtained in this study is not contradict to that of the qualitative methods, and affords the basis for the further ecological consideration. It seems that the change of the fossil fauna does not necessarily correspond with the change of the macrofeatures of the lithology.

(3) The one cause why 12 samples are not grouped with each other is considered that the samples were collected from the wide area spanning a long time. The wide area spanning a long time should include many natural environ- 
ments and many assemblages of foraminiferal fauna corresponding to those environments.

(4) It is left for the further considerations whether or not increase of the number of samples leads to the conclusion that the change of the fossil assemblages corresponds with the change of the microfeatures of the lithology. It is important to solve this problem that the minute changes of foraminiferal fauna and lithofacies at an outcrop are investigated at first and then any rule or definite relationship between foraminiferal fauna and lithofacies may be recognized, and based on its results the relationships between foraminiferal fauna and lithofacies in wide area are examined.

It is necessary to decide the accurate assemblage of the calculated groups (A to $\mathrm{Q}$ ) that the R-mode (species by species) analysis is examined.

\section{References}

Buzas, M. A. (1968): On the spatial distribution of foraminifera. Cushman Found. Foram. Research Contr., 19, 1-11, 1 pl., 5 text-figs.

KAESLER, R. L. (1966): Quantitative re-evaluation of ecology and distribution of recent foraminifera and ostracoda of Todos Santos Bay, Baja California, Mexico. The University of Kansas Paleontological Contributions-Paper 10. 1-50.

KameYama, Tokuhiko (1969. M.S.): Cluster analysis of the benthonic foraminifera of the Miyazaki Group. M. Sc. Thesis of Kyushu Univ.

Mello, J. F. and BuzAS, M. A. (1968) : An application of cluster analysis as a method of determining biofacies. Jour. Paleont., 42, (3), 747-758.

Morisita, Masaaki (1959a): Measuring of interspecific association and similarity between communities. Mem. Fac. Sci. Kyushu Univ., (E)., 3, (1), 66-80. $(1959 \mathrm{~b})$ : Measuring of the dispersion of individuals and analysis of the distributional patterns. ibid., 2, (4), 215-235.

MURATA, Shigeo (1951): On the paleo-ecological investigation of the fossil foraminiferal fauna in the Miyazaki Group. With description of new species. Bull. Kyushu Inst. Technology, 1, 61-90, 1 text-fig., 6 tables.

ONo, Yuiti (1962): On the habitat preference of Ocypoid Crabs, I. Mem. Fac. Sci. Kyushu Univ., (E)., 3, (2), 143-163.

(1965) : On the ecological distribution of Ocypoid Crabs in the estuary. ibid., 4, (1), 1-60.

OTUkA, Yanosuke (1930): Some geological problems at the Takanabe district, Miyazaki Prefecture. Geogr. Rev., 6, (7), 496-522 (in Japanese).

SANDERS, H. L. (1958): Benthonic studies in Buzzards Bay, I. Animal-Sediment relationships. Oceanogr., 3, 245-258.

Shuto, Tsugio (1952): Stratigraphical study of the Miyazaki Group. Sci. Rep. Fac. Sci. Kyushu Univ., Geology, 4, (1), 1-40, 4 text-figs., 4 tables, 8 pls. (in Japanese).

(1961) : Paleontological study of the Miyazaki Group. - A general account of the faunas-. Mem. Fac. Sci. Kyushu Univ., (D), 10, (2), 73-206, 3 pls.

Sokal, R. R. and SNeath, P. H. A. (1963): Principles of numerical taxonomy. W. H. Freeman and Company. 1-359.

TAgawa, Hideo (1964): A study of the volcanic vegetation in Sakurajima, south-west Japan I. Dynamics of vegetation. Mem. Fac. Sci. Kyushu Univ., (E), 3, (3-4), $165-228$.

UCHIO, Takayasu (1947): Geology of the Miyazaki district. Jour. Geol. Soc. Japan, $53,622-627$ (in Japanese).

Yokoyama, Matajiro (1928): Pliocene shells from Hyuga. Jour. Fac. Sci. Imp. Univ. Tokyo, Sect. 2, 1, (9), 313-364. 


\begin{tabular}{|c|c|c|c|c|c|c|c|c|c|c|c|c|c|c|c|c|c|c|c|c|c|c|c|c|c|c|c|c|c|c|c|c|c|c|c|c|c|c|c|c|c|c|c|c|c|c|c|c|c|c|c|}
\hline $\begin{array}{ll}\text { Species name } & \text { Sample number } \\
\end{array}$ & $|1131|^{1}$ & 11301 & \begin{tabular}{l|l}
1119 & 66
\end{tabular} & $62 \mid 64$ & $64 \mid 852$ & 291199 & 85537 & $1169 \mid 11$ & & 8540 & $\left.1102\right|_{8} ^{8}$ & 30041 & $143 \mid 850$ & ${ }^{7} \mid 116$ & $5 \mid 1214$ & $|179|^{8}$ & 822485 & 311211 & 58 & 10485 & 5098548 & $\left.1109\right|_{1} ^{1}$ & $1123 \mid 118$ & $85 \mid 1217$ & $|181|$ & $1184 \mid 114$ & $48 \mid 177$ & 1175 & 855285 & $521 \mid 151$ & 51 & \begin{tabular}{l|l}
30 & 46 \\
\end{tabular} & 49 & \begin{tabular}{l|l}
68 & 122 \\
\end{tabular} & $220|8545|$ & 1145 & 1146 & $5|147|_{1}^{1}$ & 1218 | $6:$ & $3: 97$ & 8513 & 38 & $\begin{array}{lll}60 & 100 \\
\end{array}$ & & 99 & & & $|1206|^{1}$ & 120985 & 121212 & \\
\hline 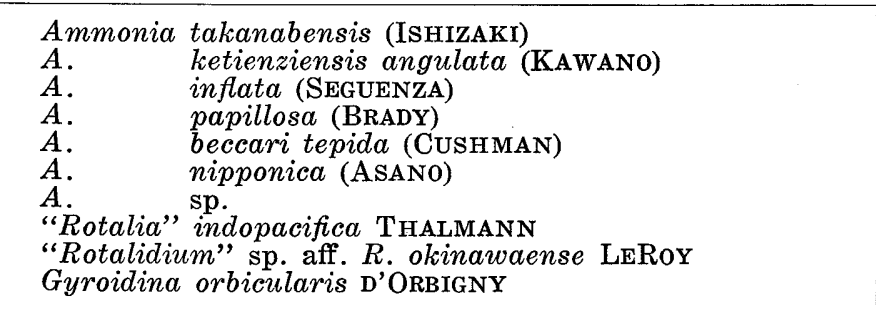 & 16 & ${ }^{10}$ & 14 & \begin{tabular}{l|l}
3 & 6 \\
1 &
\end{tabular} & \begin{tabular}{c|}
68 \\
88
\end{tabular} & \begin{tabular}{l|l}
4 & 14
\end{tabular} & & \begin{tabular}{l|l}
2 & 8 \\
12 & 8
\end{tabular} & \begin{tabular}{l|l}
82 & 24 \\
24
\end{tabular} & & $\begin{array}{l}4 \\
4\end{array}$ & 2 & & $\begin{array}{l}10 \\
22\end{array}$ & \begin{tabular}{l|l|}
0 & 18 \\
24 &
\end{tabular} & $\mid \begin{array}{c}40 \\
64\end{array}$ & ${ }_{44}$ & \begin{tabular}{l|l}
2 & 32
\end{tabular} & 14 & ${ }^{40}$ & 158 & 2 & 4 & 2 & 48 & $\begin{aligned} \frac{38}{232} \\
232\end{aligned}$ & \begin{tabular}{l|l}
8 & 22 \\
310
\end{tabular} & $\mid \begin{array}{l}4 \\
74\end{array}$ & \begin{tabular}{l|l}
1114 & 1 \\
4
\end{tabular} & $\begin{array}{l}14 \\
\frac{14}{60} \\
0236\end{array}$ & 170 & \begin{tabular}{l|l}
29 & 62 \\
\end{tabular} & 58 & \begin{tabular}{|l|l|l}
108 & 6 \\
192 & 60 \\
20
\end{tabular} & \begin{tabular}{|l|l|}
64 & 2 \\
8 & 2 \\
\end{tabular} & \begin{tabular}{|l|l|l}
20 & 9 \\
32 & 9 \\
& 1 \\
& & \\
\end{tabular} & \begin{tabular}{|l|l}
96 & 4 \\
16 & 4 \\
& 20
\end{tabular} & 4 & \begin{tabular}{l|l}
24 & $\frac{2}{2}$
\end{tabular} & \begin{tabular}{l|l}
26 & 80 \\
168
\end{tabular} & 108 & ${ }_{16}$ & 58 & $\begin{array}{l}38 \\
88 \\
88\end{array}$ & & \begin{tabular}{c|c}
96 & 1 \\
152 & 8 \\
1
\end{tabular} & & \begin{tabular}{|c|}
20 \\
348 \\
\end{tabular} & \begin{tabular}{|c|c|c|}
40 & 40 \\
312 & 168 \\
8 & 168 \\
8 & 168
\end{tabular} & \begin{tabular}{|l|l}
10 & 6 \\
8 & 36 \\
8
\end{tabular} & \\
\hline 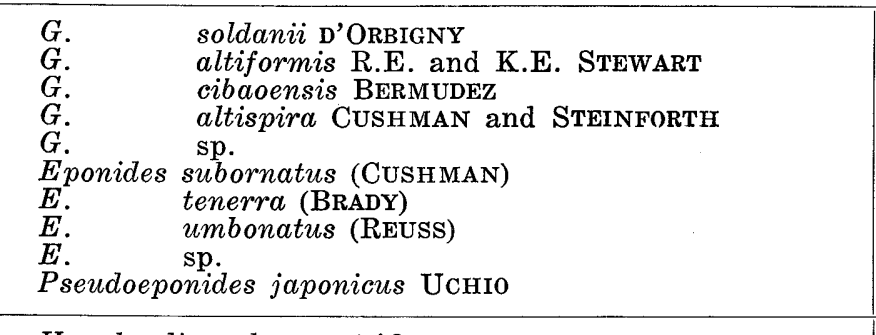 & ${ }_{32}$ & ${ }_{30}$ & $\begin{array}{r}2 \\
12 \\
12\end{array}$ & \begin{tabular}{l|l}
1 & 1 \\
1 & 1
\end{tabular} & $12 \mid 26$ & 8 & & \begin{tabular}{l|l}
4 & \\
6 & 2
\end{tabular} & \begin{tabular}{l|l}
2 & $\begin{array}{c}10 \\
4\end{array}$ \\
24 & 100
\end{tabular} & 16 & $\begin{array}{r}14 \\
4\end{array}$ & $12 \mid$ & 9 & \begin{tabular}{l|l}
2 & 4
\end{tabular} & \begin{tabular}{l|l|} 
& 4 \\
4
\end{tabular} & 4 & 40 & \begin{tabular}{l|l}
4 & 20 \\
\end{tabular} & & $\begin{array}{l}16 \\
16\end{array}$ & & & \begin{tabular}{l|l}
4 & \\
& \\
6 & \\
4 & 4 \\
4 & 2 \\
\end{tabular} & \begin{tabular}{c|c}
4 & \\
42 & 2 \\
44 & 34 \\
\end{tabular} & $\mid \begin{array}{l}4 \\
4\end{array}$ & $\begin{array}{r}32 \\
80 \\
16 \\
112 \\
32\end{array}$ & ${ }^{4}$ & & & & 20 & & & \begin{tabular}{|l|l|}
36 \\
\end{tabular} & & $\begin{array}{lll}5 & 5 \\
8 & 2\end{array}$ & \begin{tabular}{l|l}
52 & $\frac{4}{10}$ \\
20 & 4
\end{tabular} & \begin{tabular}{l|l|l}
4 & 39 \\
4 & 27
\end{tabular} & ${ }^{44}$ & $\begin{array}{l}4 \\
2 \\
2\end{array}$ & 4 & ${ }^{10}$ & & & 12 & ${ }^{64}$ & ${ }_{4}^{2}$ & & & \begin{tabular}{l|l|l}
8 & 12 \\
\end{tabular} & \\
\hline 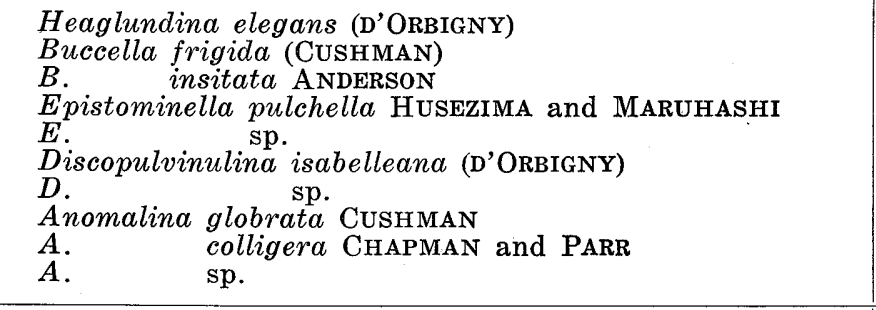 & & & $\begin{array}{l}2 \\
2 \\
2\end{array}$ & & 8 & ${ }_{4}{ }^{24}$ & $|144|$ & & \begin{tabular}{l|l}
20 & 8
\end{tabular} & & 14 & \begin{tabular}{r|r|}
30 \\
30
\end{tabular} & $3_{3}^{3}$ & 30 & \begin{tabular}{l|l}
0 & 16
\end{tabular} & & 36 & \begin{tabular}{|l|l}
18 & 12 \\
18 &
\end{tabular} & & $\left.8\right|^{2}$ & ${ }^{22}{ }_{14}$ & \begin{tabular}{|c|}
36 \\
8
\end{tabular} & & $\begin{array}{r}2 \\
32\end{array}$ & 16 & 16 & 42 & & & 6 & 10 & 7 & 2 & \begin{tabular}{|l|l|}
12 \\
\end{tabular} & & \begin{tabular}{l|l}
8 & 7 \\
2 &
\end{tabular} & 76 & 21 & 30 & 6 & & & 每4 & \begin{tabular}{c|l}
0 & 24
\end{tabular} & & & 2 & & & $\begin{array}{lll}36 & 24\end{array}$ & \\
\hline 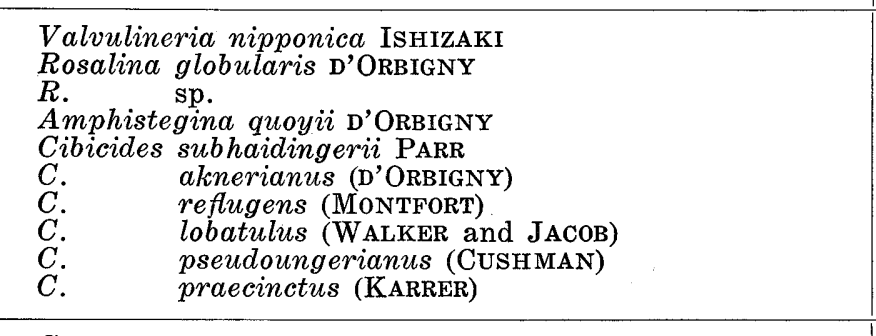 & $\begin{array}{l}16 \\
{ }_{78}^{16} \\
72\end{array}$ & \begin{tabular}{c|c}
14 & \\
14 & \\
58
\end{tabular} & & \begin{tabular}{l|l}
16 & 4 \\
29 & 3 \\
& 3 \\
\end{tabular} & $\begin{array}{l}44 \\
32 \\
12\end{array}$ & \begin{tabular}{c|c}
6 & 16 \\
6 & 16 \\
& 8
\end{tabular} & ${ }_{16}$ & \begin{tabular}{l|l}
22 & 1 \\
12 &
\end{tabular} & $12{ }^{12}$ & 22 & $\begin{array}{l}8 \\
4\end{array}$ & 40 & & 38 & \begin{tabular}{|l|l|l|}
8 & 58 \\
\end{tabular} & \begin{tabular}{|c|c|c|}
76 \\
4 \\
4
\end{tabular} & \begin{tabular}{l|l}
80 \\
80 \\
4
\end{tabular} & $\begin{array}{l}\frac{6}{6} \\
10^{2}\end{array}$ & 18 & $\begin{array}{r}48 \\
8 \\
8\end{array}$ & $\begin{array}{c}24 \\
26 \\
50\end{array}$ & 8 & \begin{tabular}{l|l}
50 & 1 \\
50
\end{tabular} & $\begin{array}{l}10 \\
\frac{10}{74} \\
6\end{array}$ & \begin{tabular}{|r|}
88 \\
4
\end{tabular} & \begin{tabular}{l|l}
32 & $\frac{12}{22}$
\end{tabular} & \begin{tabular}{l|l}
2 & 4 \\
20 & 22
\end{tabular} & 24 & \begin{tabular}{|c|c|}
${ }_{50}^{8}$ & 3 \\
\end{tabular} & $\begin{array}{ll}30 & 96 \\
28\end{array}$ & $\frac{12}{176}$ & \begin{tabular}{l|l}
39 & 38 \\
&
\end{tabular} & $\begin{array}{ll}36 \\
36\end{array}$ & $\begin{array}{l}48 \\
12 \\
48\end{array}$ & ${ }_{3}^{3}$ & \begin{tabular}{|l|l|}
56 & 4 \\
& 12 \\
144 & 276 \\
\end{tabular} & \begin{tabular}{c|c}
44 & \\
12 & 32 \\
276 & 138 \\
\end{tabular} & $\begin{array}{r}24 \\
9 \\
114\end{array}$ & $\begin{array}{ll}108 \\
2 \\
2\end{array}$ & \begin{tabular}{l|l}
12 & 64 \\
26 & 88 \\
2 & 88 \\
\end{tabular} & 3 & \begin{tabular}{c|}
${ }^{4}$ \\
${ }^{12}$ \\
46
\end{tabular} & & 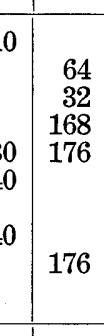 & & $\begin{array}{r}1^{8} \\
7^{8}\end{array}$ & & & & $\begin{array}{r}6 \\
36\end{array}$ & \\
\hline 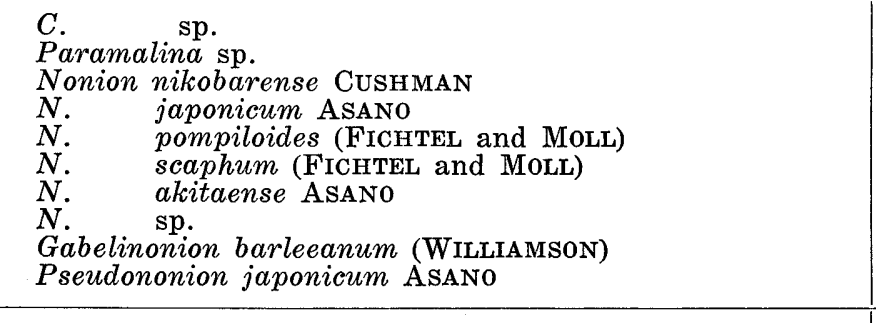 & \begin{tabular}{r|r}
88 \\
8
\end{tabular} & $488^{11}$ & 188 & \begin{tabular}{l|l}
9 & \\
4 & 4
\end{tabular} & $\begin{array}{c}4 \\
44\end{array}$ & \begin{tabular}{l|l}
6 & \\
2 & 24
\end{tabular} & ${ }^{24}$ & 23 & \begin{tabular}{l|l}
32 & 2 \\
2 & 4 \\
\end{tabular} & & \begin{tabular}{|c|}
22 \\
14 \\
4 \\
8 \\
6
\end{tabular} & \begin{tabular}{l|l}
48 \\
\end{tabular} & \begin{tabular}{l|l}
24 & 18
\end{tabular} & 28 & \begin{tabular}{l|l}
8 & 64 \\
& 64 \\
6 &
\end{tabular} & \begin{tabular}{r|r}
104 \\
2
\end{tabular} & \begin{tabular}{l|l}
104 & 7
\end{tabular} & \begin{tabular}{l|l}
72 & 8 \\
188
\end{tabular} & $\begin{array}{r}4 \\
10 \\
2 \\
2\end{array}$ & \begin{tabular}{l|l}
16 & $:$ \\
40 & \\
8 & \\
\end{tabular} & $\begin{array}{l}4 \\
2\end{array}$ & \begin{tabular}{|c|}
12 \\
8
\end{tabular} & 20 & & \begin{tabular}{|l|l}
16 \\
\end{tabular} & \begin{tabular}{c|c}
144 & $\frac{6}{16}$ \\
16 & $\frac{19}{8}$
\end{tabular} & \begin{tabular}{c|c}
6 & 6 \\
2 & 6
\end{tabular} & 2 & $\mid \begin{array}{l}16 \\
2\end{array}$ & \begin{tabular}{l|l|l}
2 & 44 \\
4
\end{tabular} & $\begin{array}{l}2 \\
6 \\
4 \\
4 \\
2\end{array}$ & \begin{tabular}{l|l} 
& 1 \\
7 & 28
\end{tabular} & & $\begin{array}{rl}28 & 2 \\
204 & 2 \\
24 & 1\end{array}$ & $\begin{array}{l}24 \\
24 \\
12\end{array}$ & \begin{tabular}{|l|l|l|l|}
82 & 10 \\
4 & \\
\end{tabular} & \begin{tabular}{r|r}
8 & 92 \\
104 & 92 \\
\end{tabular} & $\begin{array}{ll}12 \\
9\end{array}$ & \begin{tabular}{l|l}
10 & 1 \\
10 &
\end{tabular} & \begin{tabular}{|r|r|}
14 & 48 \\
2 & 120 \\
2 & 32 \\
8 & 8 \\
& 8 \\
\end{tabular} & $\begin{array}{r}4 \\
48 \\
4\end{array}$ & $\begin{array}{l}4 \\
2\end{array}$ & \begin{tabular}{r|r}
8 \\
12 \\
18 \\
6 \\
\end{tabular} & \begin{tabular}{l|l} 
& \\
0 & \\
0 & 88 \\
\end{tabular} & & \begin{tabular}{|l|l}
232 & \\
24 & \\
24
\end{tabular} & \begin{tabular}{c|c}
4 & 4 \\
2 & 4 \\
14 & 12 \\
\end{tabular} & ${ }^{4}$ & $\begin{array}{l}40 \\
6\end{array}$ & $\begin{array}{c}8 \\
88 \\
16\end{array}$ & \\
\hline 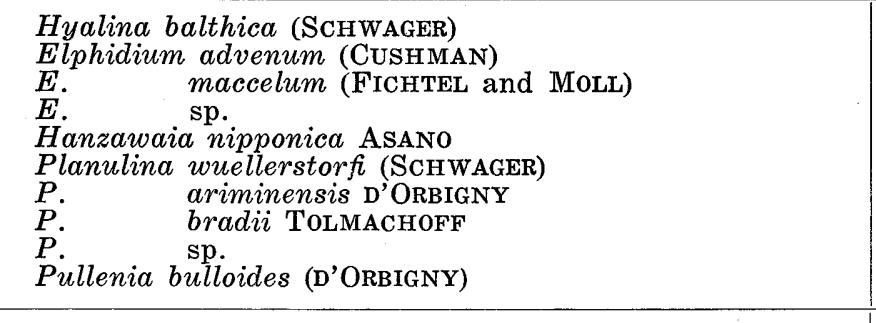 & 128 & \begin{tabular}{r|}
22 \\
8 \\
8
\end{tabular} & 2 & & & $\begin{array}{l}{ }_{760}^{60} \\
72\end{array}$ & 8 & & & & 8 & 12 & & ${ }_{6}^{2}$ & 2 & 4 & & 2 & 2 & $\mid$\begin{tabular}{|l|l|}
32 \\
\end{tabular} & & & & 2 & $|12| 4$ & 448 & $8 \mid$ & & 2 & & 2 & 3 & & \begin{tabular}{l|l}
168 & 6 \\
& \\
2 & \\
3 & 2 \\
9 & 9 \\
4 &
\end{tabular} & \begin{tabular}{c|}
60 \\
28 \\
36 \\
24 \\
96 \\
48
\end{tabular} & \begin{tabular}{l|l}
52 & 24 \\
28
\end{tabular} & \begin{tabular}{l|l|}
24 & 14 \\
28 &
\end{tabular} & 3 & 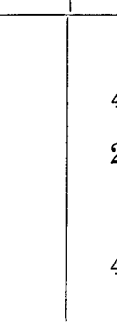 & \begin{tabular}{l|l}
4 & 120 \\
&
\end{tabular} & & & & & 20 & 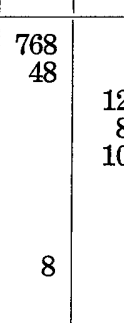 & & ${ }_{4}$ & & & \\
\hline 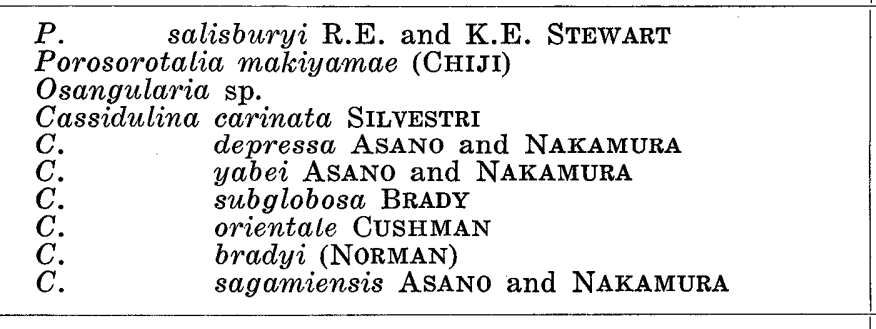 & & 2 & 16 & \begin{tabular}{l|l|l}
14 & 56
\end{tabular} & 56 & \begin{tabular}{l|l}
2 & 80 \\
24
\end{tabular} & 56 & \begin{tabular}{|l|}
2 \\
\end{tabular} & 2 & & \begin{tabular}{l|l}
4 \\
\end{tabular} & & & 4 & \begin{tabular}{|l|l|}
4 & 8 \\
\end{tabular} & ${ }^{12}$ & & $\begin{array}{l}2 \\
11 \\
4\end{array}$ & 4 & 128 & & 12 & $\begin{array}{l}6 \\
2\end{array}$ & \begin{tabular}{l|l}
34 & 4
\end{tabular} & & 128 & 26 & $\frac{2}{2}$ & & 2 & & & & 36 & 2 & & 4 & $\begin{array}{r}3 \\
12 \\
6\end{array}$ & \begin{tabular}{l|l}
10 & 26 \\
2 & 10
\end{tabular} & \begin{tabular}{r|r}
16 \\
10 \\
248
\end{tabular} & & 6 & & \begin{tabular}{l|l}
0 \\
0
\end{tabular} & $\begin{array}{r}12 \\
4\end{array}$ & \begin{tabular}{r|}
16 \\
8 \\
\end{tabular} & 6 & & & & \\
\hline 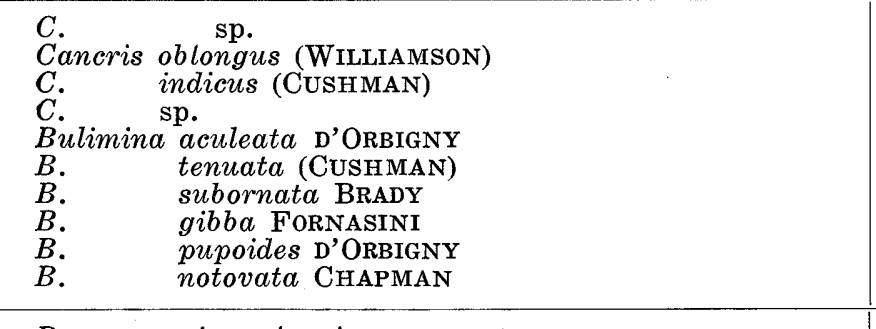 & $\begin{array}{r}8 \\
88\end{array}$ & & 2 & \begin{tabular}{ll|l}
26 & 38
\end{tabular} & 80 & $\begin{array}{cc}8 & 128 \\
32 \\
32\end{array}$ & 20 & $\begin{array}{c}{ }^{44} \\
4\end{array}$ & \begin{tabular}{l|l}
4 & 10 \\
4
\end{tabular} & & 10 & & 14 & $\begin{array}{l}4 \\
4\end{array}$ & 48 & 8 & 12 & \begin{tabular}{l|l}
$4 \quad 32$
\end{tabular} & & $\begin{array}{r}16 \\
128 \\
144\end{array}$ & 8 & & & $\begin{array}{l}6 \\
4 \\
4\end{array}$ & 56 & 64 & \begin{tabular}{l|l}
6 & 30
\end{tabular} & & & $\begin{array}{ll}18 & \frac{12}{12} \\
\frac{2}{8} & 12\end{array}$ & 20 & 10 & & \begin{tabular}{|l|l}
120 & 8 \\
\end{tabular} & 84 & 54 & \begin{tabular}{|l|l|}
4 & 10 \\
4 & 36 \\
\end{tabular} & \begin{tabular}{|c|}
3 \\
30 \\
30
\end{tabular} & 2 & $\begin{array}{l}16 \\
8 \\
40\end{array}$ & & $\begin{array}{l}4 \\
8 \\
2\end{array}$ & $\begin{array}{l}2 \\
4\end{array}$ & i. & ${ }_{4}^{8}$ & $\begin{array}{l}8 \\
8\end{array}$ & 总4 & ${ }^{4}$ & & 10 & \\
\hline 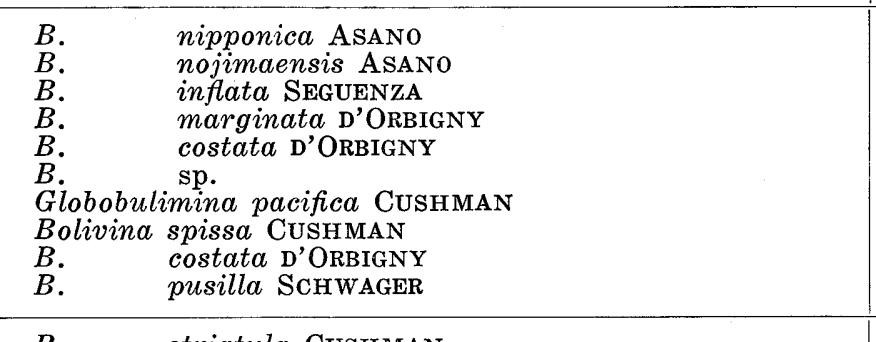 & & 2 & & \begin{tabular}{l|l}
9 & 16 \\
4 & 16
\end{tabular} & $\begin{array}{l}16 \\
12\end{array}$ & $\begin{array}{l}\frac{1}{104} \\
3_{22}^{2}\end{array}$ & & 44 & \begin{tabular}{l|l|l}
4 & 85
\end{tabular} & ${ }^{6}$ & \begin{tabular}{|l|l}
12 \\
|
\end{tabular} & & $\begin{array}{l}3 \\
2\end{array}$ & \begin{tabular}{l|l}
8 & 38
\end{tabular} & 40 & 56 & & 60 & & 72 & 2 & & \begin{tabular}{l|l}
222 & 16
\end{tabular} & \begin{tabular}{l|l|l|}
16 & 118
\end{tabular} & $\begin{array}{lll}164 & 7\end{array}$ & 736 & 2 & & 2 & \begin{tabular}{l|l}
2 & 4
\end{tabular} & 38 & \begin{tabular}{l|l}
6 & 6
\end{tabular} & & \begin{tabular}{l|l}
108 & 1
\end{tabular} & 12 & 64 & 8 & $\mid \begin{array}{r}3 \\
3 \\
57\end{array}$ & \begin{tabular}{l|l}
${ }_{10}$ & 118 \\
\end{tabular} & \begin{tabular}{l|l}
8 & 64 \\
6 & 32
\end{tabular} & & 62 & $\begin{array}{l}30 \\
10 \\
10\end{array}$ & $\begin{array}{l}0 \\
0 \\
0 \\
0\end{array}$ & 20 & 104 & & & & $\begin{array}{c}12 \\
6 \\
6 \\
12 \\
12\end{array}$ & \\
\hline 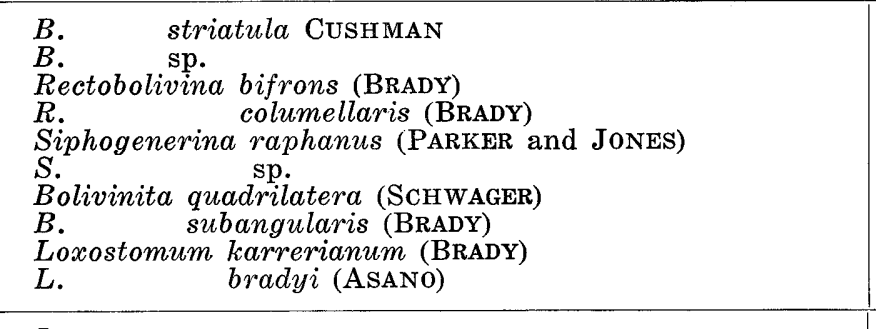 & \begin{tabular}{l|l}
16 & \\
24 & 1 \\
80 & 1
\end{tabular} & $\begin{array}{l}108 \\
32\end{array}$ & $\begin{array}{l}18 \\
16\end{array}$ & $\begin{array}{c}11 \\
11 \\
31 \\
31\end{array}$ & 4 & \begin{tabular}{|c|c|c|} 
& 256 \\
2 & 24 \\
\end{tabular} & $\begin{array}{r}156 \\
4\end{array}$ & \begin{tabular}{l|l|l}
70 & 148
\end{tabular} & \begin{tabular}{l|l|l}
184 & 124
\end{tabular} & ${ }_{46}^{2}$ & ${ }_{42}^{6}$ & \begin{tabular}{l|l}
24 \\
56
\end{tabular} & & $\begin{array}{r}2 \\
16 \\
4\end{array}$ & $\begin{array}{l}10 \\
16 \\
12\end{array}$ & 8 & \begin{tabular}{l|l}
56 & 2 \\
16 & 2
\end{tabular} & \begin{tabular}{|l|l}
16 \\
36 \\
40
\end{tabular} & 2 & $\begin{array}{c}16 \\
32 \\
32 \\
8\end{array}$ & ${ }^{2}$ & & ${ }_{30}^{6}$ & \begin{tabular}{c|c}
6 & 2 \\
6 & 12
\end{tabular} & ${ }_{56}$ & 64 & 6 & 6 & 44 & 208 & $\begin{array}{l:}4 \\
2\end{array}$ & \begin{tabular}{l|l}
13 & 14
\end{tabular} & 12 & \begin{tabular}{c|c}
96 & 4 \\
168. & 10 \\
48 &
\end{tabular} & & \begin{tabular}{l|l}
30 & 4 \\
&
\end{tabular} & \begin{tabular}{r|r|}
44 & 4 \\
4 & 16
\end{tabular} & $\begin{array}{l}177 \\
15\end{array}$ & & \begin{tabular}{l|l}
10 & 312 \\
22 &
\end{tabular} & 20 & 50 & \begin{tabular}{l|l|l}
8 & 20 \\
& 50 \\
\end{tabular} & \begin{tabular}{|l|l}
60 \\
83
\end{tabular} & \begin{tabular}{r|r}
8 \\
68 \\
16
\end{tabular} & \begin{tabular}{r|r}
488 & 60 \\
24 & 20 \\
816 & 36 \\
\end{tabular} & \begin{tabular}{l|l}
60 & 30 \\
2 & 12 \\
36 & 10 \\
& 10 \\
\end{tabular} & & & 12 & \\
\hline 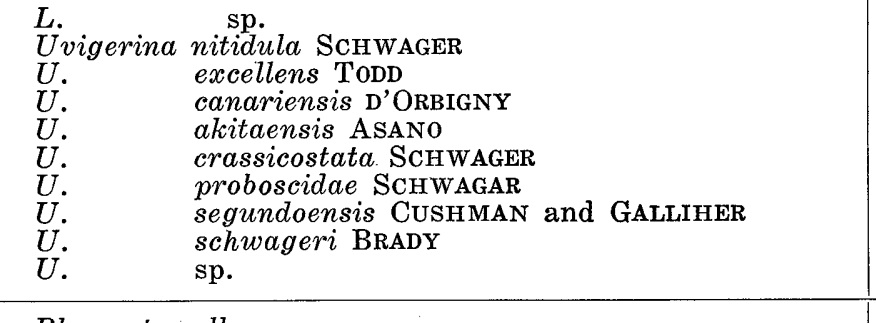 & \begin{tabular}{l|l}
32 & 1 \\
72 & 1
\end{tabular} & $\begin{array}{l}10 \\
16\end{array}$ & ${ }^{14}$ & \begin{tabular}{l|l}
6 & 12
\end{tabular} & & $\begin{array}{l}8 \\
8120 \\
168 \\
96\end{array}$ & & 8 & 2 & 4 & ${ }^{34}$ & ${ }^{76}$ & $\begin{array}{l}8 \\
10\end{array}$ & 56 & 58 & 40 & $\frac{20}{2}$ & \begin{tabular}{l|l}
0 & 14 \\
2
\end{tabular} & ${ }_{132}$ & \begin{tabular}{l|l}
768 & 36.
\end{tabular} & $\begin{array}{lll}34 & 216\end{array}$ & \begin{tabular}{l|l}
60 & 1
\end{tabular} & $\begin{array}{ll}128 & 146\end{array}$ & \begin{tabular}{l|l}
6 & 68
\end{tabular} & 3218 & 396 & 28 & 16 & & & 32 & & & & & & $\begin{array}{r}16 \\
6 \\
12\end{array}$ & & 54 & \begin{tabular}{|l}
4 \\
4 \\
4 \\
716 \\
724 \\
16
\end{tabular} & 4 & & $\begin{array}{l}2 \\
2500 \\
250\end{array}$ & & ${ }_{24}$ & & & & & 72 & \\
\hline 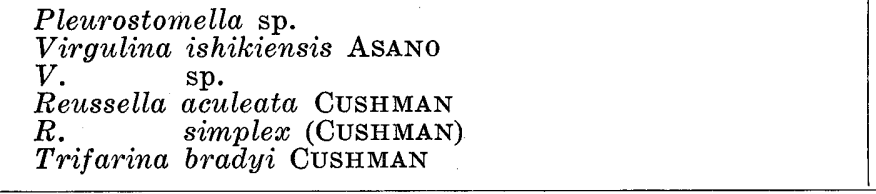 & & & & 1 & & 8 & & 2 & & & 1 & & & & & & & & 2 & & & & & 2 & & & & & & & & 2 & & & & & & & 6 & 8 & & & & 24 & & & & & & & \\
\hline
\end{tabular}




\begin{tabular}{|c|c|c|c|c|c|c|c|c|c|c|c|c|c|c|c|c|c|c|c|c|c|c|c|c|c|c|c|c|c|c|c|c|c|c|c|c|c|c|c|c|}
\hline $\begin{array}{ll}\text { Spocies name } & \text { Sample number } \\
\end{array}$ & $\left.1131\right|_{1138}$ & 611196 & $62 \mid 64855$ & :529|11998 8 & 5377 1169 & $\mid 1142$ & 508540 & 111028500 & $4 \mid 1438$ 8 8 & 85071116 & 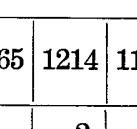 & 1798 8524] & $85311_{12}$ & 201158 & 10480509 & 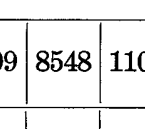 & $091123 \mid$ & $\left.1185\right|_{121} ^{121}$ & 17] 1818 & $|1884|_{11}$ & $48|1177|$ & $|1175|_{8}^{8}$ & 652855 & 421151 . 5 & \begin{tabular}{l|l}
51 & 30 \\
\end{tabular} & 46 & & 12028656 & 51014511 & $146[11255$ | & $\mid 1477^{212}$ & 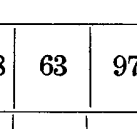 & $97|85313|^{32}$ & 38601 & $\left.100\right|_{1313}$ & 3929 & $91|105|$ & $|108| 2006 \mid$ & 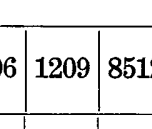 & \\
\hline 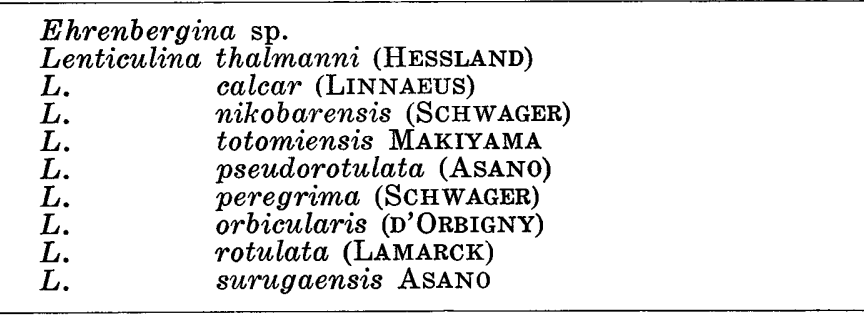 & $\begin{array}{l}12 \\
2\end{array}$ & $\mid \begin{array}{l}8 \\
2 \\
6\end{array}$ & $\begin{array}{ccc}2 & 12 \\
\frac{1}{1} & 12 \\
4 & 8 \\
\end{array}$ & $\begin{array}{l}16 \\
8\end{array}$ & 2 & $=$ & \begin{tabular}{r|}
18 \\
8 \\
4
\end{tabular} & $\begin{array}{l}{ }^{6} \\
2\end{array}$ & & & 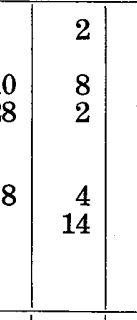 & \begin{tabular}{|c|c|}
$\frac{4}{12}$ & $\frac{4}{8}$ \\
\end{tabular} & & \begin{tabular}{l|l}
20 & 4
\end{tabular} & & 6 & & $\begin{array}{l}6 \\
2\end{array}$ & & $\mid$ & \begin{tabular}{ll|l}
12 & $\frac{12}{2}$ \\
$\frac{2}{8}$ & &
\end{tabular} & & & $\mid \begin{array}{c}12 \\
12 \\
8 \\
12 \\
12\end{array}$ & & & $\left.18\right|^{24} \begin{array}{c}24 \\
48\end{array}$ & $\mid \begin{array}{l}24 \\
48 \\
48\end{array}$ & 18 & & 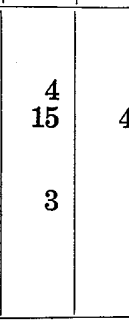 & & & & $\underbrace{20}$ & \begin{tabular}{|c|c|}
36 & $\frac{4}{3}$ \\
4 & \\
28 & \\
\end{tabular} & \begin{tabular}{|l|l|} 
& 6 \\
32 & \\
\end{tabular} & 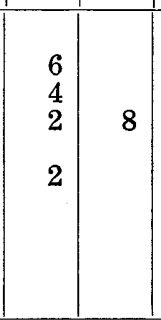 & & \\
\hline 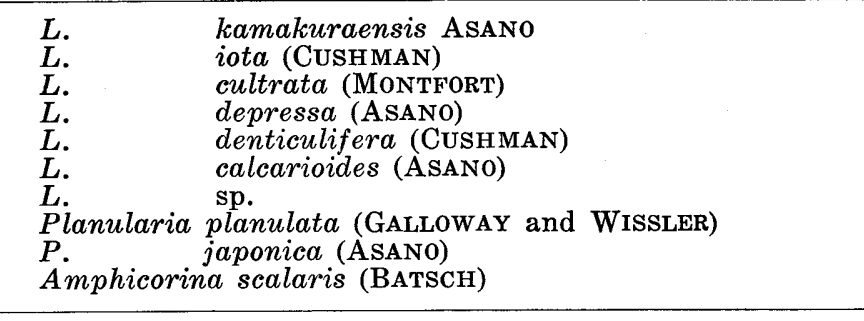 & $\begin{array}{r}40 \\
32\end{array}$ & $\begin{array}{r}6 \\
20 \\
\end{array}$ & & $\begin{array}{ccc}2 & \\
10 & 8\end{array}$ & 20 & $\left|\begin{array}{c}2 \\
22\end{array}\right|$ & ${ }_{10} 8$ & & $\left|\begin{array}{c}4 \\
11\end{array}\right|$ & & $\begin{array}{c}8 \\
8 \\
2\end{array}$ & $\begin{array}{l}4 \\
4 \\
28\end{array}$ & & \begin{tabular}{l|l}
4 & 10 \\
\end{tabular} & & ${ }_{10}$ & & 18. & & $\mid 16$ & ${ }_{10}$ & $2 \mid$ & 6 & & ${ }_{16}$ & & \begin{tabular}{l|l}
32 & 36 \\
12
\end{tabular} & $\mid \begin{array}{l}12 \\
36\end{array}$ & & 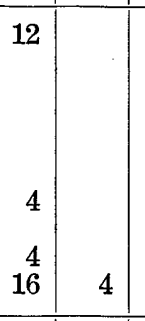 & & & & & 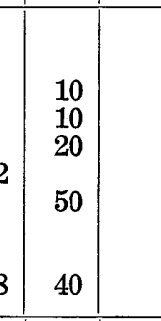 & & & $|16|$ & \begin{tabular}{l|l|l|}
8 &
\end{tabular} & \begin{tabular}{l|l}
8 & 18 \\
\end{tabular} \\
\hline 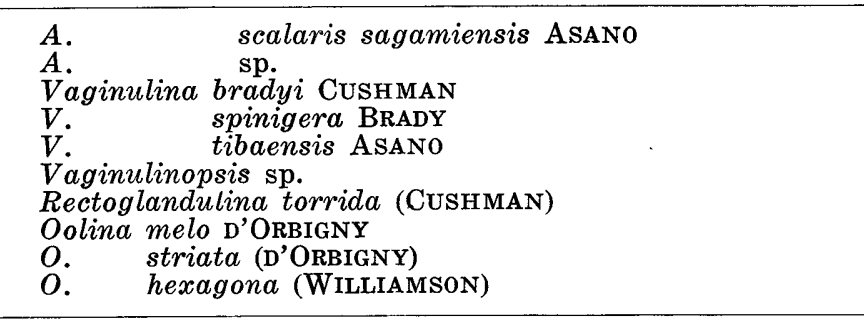 & & ${ }^{4}$ & \begin{tabular}{c|c}
5 & 8 \\
520
\end{tabular} & & & & & ${ }^{2}$ & & & \begin{tabular}{l|l}
$\frac{2}{6}$ & 2 \\
2 &
\end{tabular} & & & 8 & 16 & & & ${ }^{44}$ & $a^{2} 20$ & 量2 & & 2 & & $\mid \begin{array}{c}8 \\
12\end{array}$ & 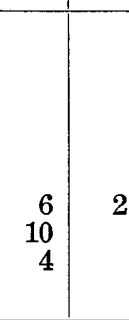 & & ${ }^{12}$ & $2\left|\begin{array}{l}4 \\
28\end{array}\right|$ & $\left|{ }_{26}^{4}\right|$ & & 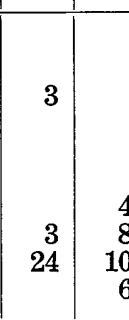 & & $\begin{array}{c}8 \\
48\end{array}$ & $\frac{6}{2}$ & $\mid \begin{array}{l}10 \\
20\end{array}$ & & $\begin{array}{r}8 \\
8 \\
56\end{array}$ & ${ }^{2}$ & & $\begin{array}{l}6 \\
6\end{array}$ \\
\hline 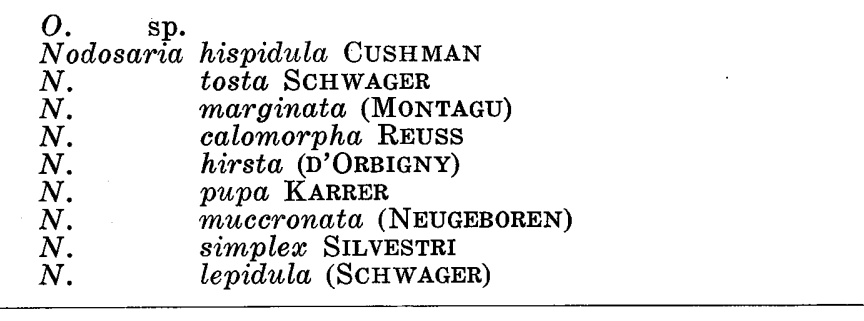 & $8 \frac{12}{2}$ & 6 & $\begin{array}{cc}5 & 12 \\
1 & 12 \\
\end{array}$ & & 2 & 2 & ${ }^{6}$ & $\frac{2}{2}$ & & & 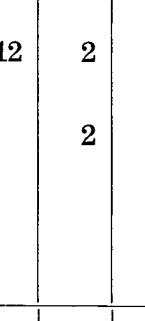 & & & \begin{tabular}{l|l}
8 & 2 \\
8 & 2
\end{tabular} & ${ }_{16}$ & 4 & & 26 & $\frac{2}{2}$ & 16 & & & & 4 & ${ }_{10}^{10}$ & & & & 32 & & \begin{tabular}{l|l}
$\frac{12}{6}$ & $\frac{18}{2}$
\end{tabular} & ${ }^{6} \frac{2}{2}$ & 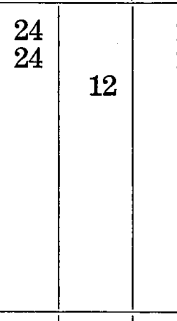 & & 1 & ${ }_{16}$ & & 2 & 8 & 18 \\
\hline 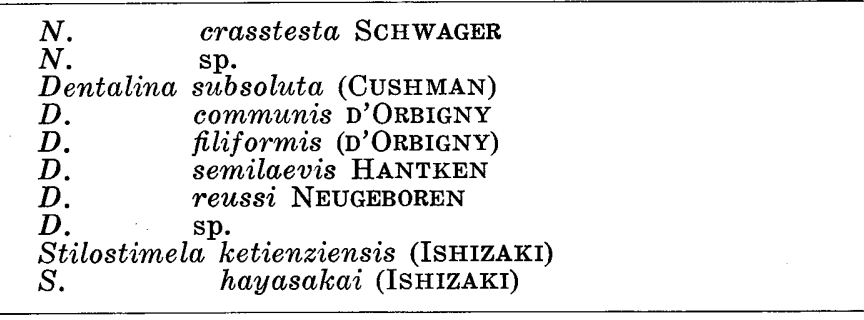 & 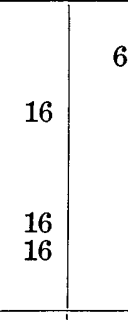 & $\mid \begin{array}{cc}6 \\
10\end{array}$ & 8 & ${ }^{8}$ & $\frac{6}{2}$ & & ${ }^{2}{ }_{4}$ & & & ${ }_{18}$ & ${ }^{6}$ & 4 & & \begin{tabular}{l|l}
8 & 2 \\
4 &
\end{tabular} & & ${ }^{8}$ & & & 8 & 32 & & & & ${ }_{16} 16$ & & 818 | & \begin{tabular}{l|l}
8 & 12 \\
24
\end{tabular} & | & & \begin{tabular}{ll|l}
$\frac{12}{12}$ & \\
$\frac{12}{20}$ & & \\
\end{tabular} & 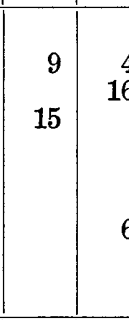 & & 8 & & $\begin{array}{l}10 \\
20\end{array}$ & & $\begin{array}{l}8 \\
8\end{array}$ & & & ${ }_{12}$ \\
\hline 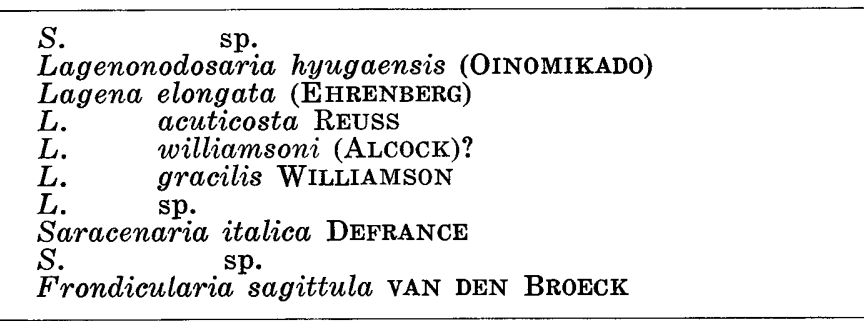 & ${ }^{8}$ & ${ }^{2}$ & ${ }^{8}$ & 8 & & & & & & ${ }^{6}$ & & 12 & & ${ }_{12}$ & & & & ${ }_{10}$ & 4 & & & ${ }^{4}$ & & 2 & & & ${ }_{4}^{424}$ & & 4 & & ${ }_{3}$ & & & & & & & & & \\
\hline 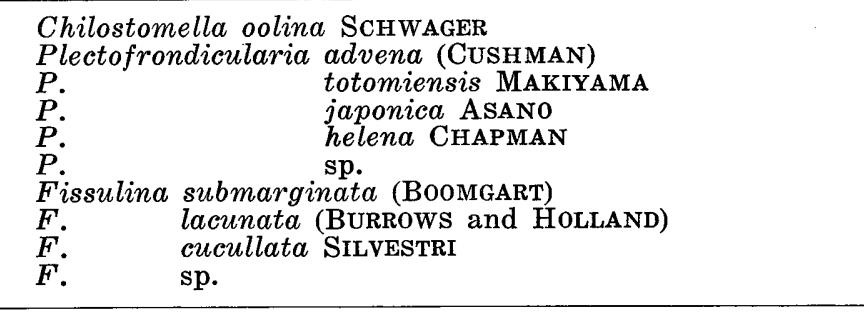 & \begin{tabular}{c|c}
8 & 4 \\
16 & 64 \\
8 & 6
\end{tabular} & $\mid$\begin{tabular}{l|}
2 \\
58 \\
32
\end{tabular} & 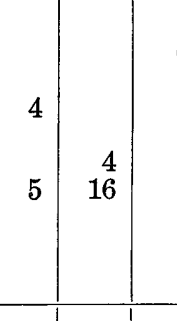 & \begin{tabular}{ll|}
6 & 16 \\
8 & 8
\end{tabular} \mid & \begin{tabular}{|c|c|}
32 & 2 \\
8 \\
6
\end{tabular} \mid & $\left|\begin{array}{c|}\frac{2}{2} \\
10 \\
\frac{2}{2}\end{array}\right|$ & & $\mid \begin{array}{l}6 \\
4 \\
4\end{array}$ & ${ }_{9}^{6}$ & $\mid \begin{array}{c}10 \\
4 \\
4 \\
4\end{array}$ & & \begin{tabular}{l|l}
4 & 4 \\
16 & 12 \\
12 &
\end{tabular} & & \begin{tabular}{c|c}
8 & 4 \\
8 & 12 \\
28 & 8
\end{tabular} & & $\mid 24$ & \begin{tabular}{|c|c|}
10 & 4 \\
40 \\
2 \\
2 \\
\end{tabular} & \begin{tabular}{|l|l|}
4 & \\
4 & 1 \\
8 & 1 \\
6 & \\
&
\end{tabular} & \begin{tabular}{l|l}
12 & 52 \\
4 & 52 \\
2 &
\end{tabular} & \begin{tabular}{|c|}
16 \\
16 \\
32
\end{tabular} & $\begin{array}{l}\frac{2}{6} \\
\frac{6}{6}\end{array}$ & \begin{tabular}{|l|}
4 \\
6 \\
6 \\
4
\end{tabular} & & $\begin{array}{l}8 \\
12\end{array}$ & \begin{tabular}{c|c}
12 & $\frac{1}{2}$ \\
8 &
\end{tabular} & \begin{tabular}{ll|l}
$\frac{1}{2}$ & 2 \\
\end{tabular} & ${ }^{4}{ }_{2}$ & $=$ & $\frac{4}{2}$ & $\begin{array}{l}2 \\
4 \\
3 \\
\frac{3}{2}\end{array}$ & $\begin{array}{ll}64 \\
24\end{array}$ & & \begin{tabular}{l|}
40 \\
16 \\
16
\end{tabular} & ${ }_{48}$ & $\left|\begin{array}{|}10 \\
10\end{array}\right|$ & & 48 & & & 8 \\
\hline 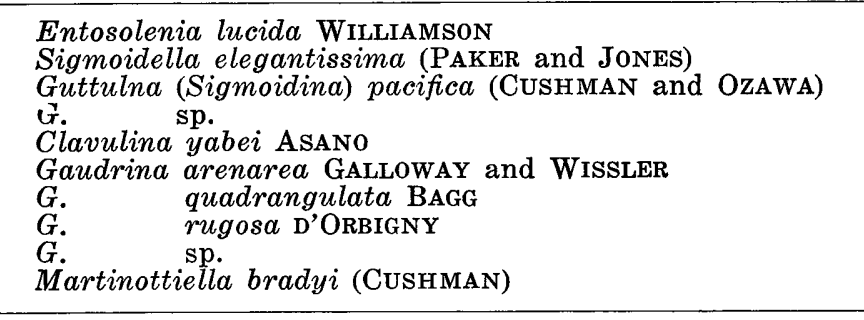 & 12 & $\left|\begin{array}{ll}60 & 3 \\
10\end{array}\right|$ & 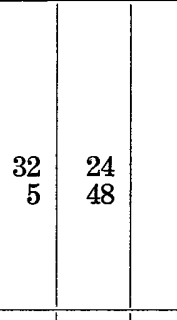 & $\begin{array}{l}8 \\
8 \\
8\end{array}$ & $\frac{54}{2}$ & $\begin{array}{l}{ }^{10} \\
2\end{array}$ & & & ${ }_{6}^{4}$ & ${ }_{20}^{40}$ & & 28 & & & 16 & & & ${ }^{30}$ & 60 & & \begin{tabular}{l|l|l|l}
6 & 12 \\
24
\end{tabular} & & & \begin{tabular}{cc|}
10 & 20 \\
& \\
64
\end{tabular} \mid & ${ }^{26}$ & 3 & & $\begin{array}{c}828 \\
28 \\
24 \\
24\end{array}$ & $\begin{array}{c}2 \\
40 \\
10 \\
14\end{array}$ & ${ }_{48}^{44}$ & \begin{tabular}{l|l}
21 & 8 \\
51 & 12
\end{tabular} & & 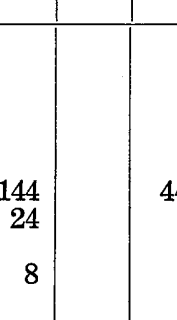 & ${ }^{44}$ & \begin{tabular}{l|l}
30 \\
50 \\
50 \\
50
\end{tabular} & $\begin{array}{ll}8 & \\
\frac{28}{28} \\
18 \\
32\end{array}$ & \begin{tabular}{r|r|r|r|r|}
8 & 2 \\
48 & $\frac{2}{2}$ \\
56 &
\end{tabular} & $\left|\begin{array}{l|}\frac{4}{2} \\
\frac{2}{6} \\
8\end{array}\right|$ & & | \\
\hline 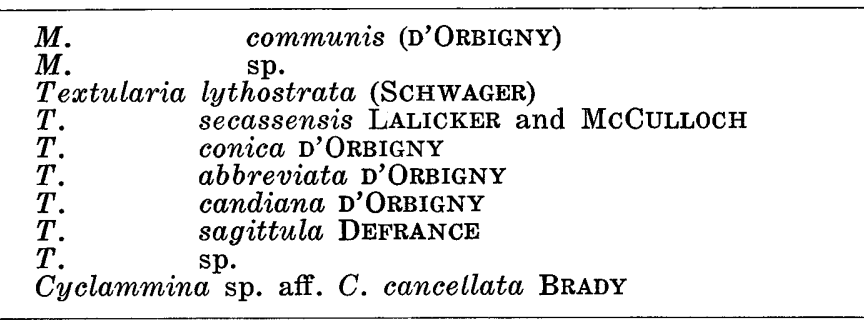 & 8 & $\frac{2}{2}$ & 8 & & & 21 & & & & ${ }^{2}$ & & & & 16 & & & & & & & & & 2 & & & & & $\begin{array}{l}4 \\
4\end{array}$ & & \begin{tabular}{|l|}
2 \\
2 \\
\end{tabular} & & & $\begin{array}{r}8 \\
48\end{array}$ & $\mid 122$ & $\begin{array}{c}200 \\
1\end{array}$ & 12 & & & & ${ }^{6}$ \\
\hline 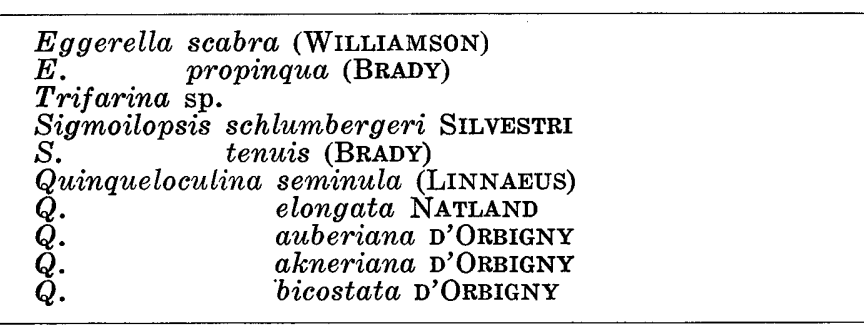 & $\begin{array}{l}72 \\
24\end{array}$ & 8 & 2282 & & 64 & 2 & & & 61 & & 44 & & & 68 & \begin{tabular}{l|l}
24 & 34
\end{tabular} & & & 26 & & $\begin{array}{c}32 \\
16\end{array}$ & & ${ }^{24}$ & & 16 20 & & ${ }^{26}$ & & 4 & 22 & ${ }_{64}{ }_{28}^{28}$ & \begin{tabular}{c|c}
63 & 12 \\
63 & 12
\end{tabular} & ${ }_{10}^{16}$ & 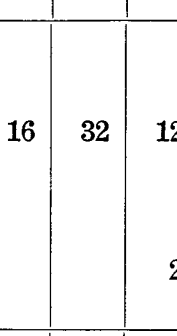 & & \begin{tabular}{|c|}
50 \\
10 \\
10 \\
00 \\
30
\end{tabular} & & 8 & 2 & & 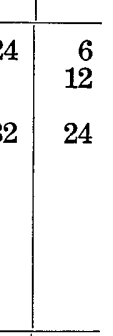 \\
\hline 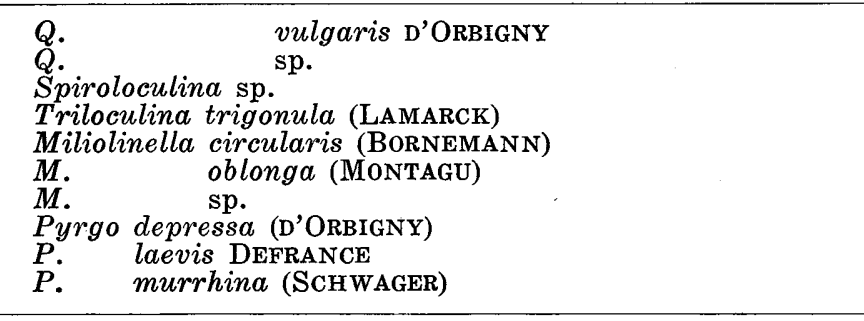 & 8 & 2 & & & & & & & 4 & & & & & & ${ }^{24}$ & & & & & & & & & & & & & 12 & & ${ }_{4}^{4}$ & & & 8 & & & & & & & \\
\hline 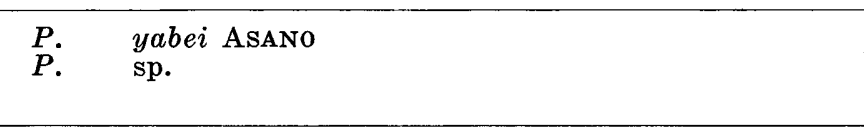 & & & & & & & & & ${ }^{1}$ & & & & & & & & & & & & & & & & & & & & & & & & & & & & & & & \\
\hline
\end{tabular}

